\title{
Rating Actions: Reliable Information or Regulatory Constraint after the Subprime Crisis?
}

\author{
Eleonora Isaia, Marina Damilano, Cristina Rovera ${ }^{1}$
}

\begin{abstract}
At the time of the subprime crisis, investors strongly blamed credit rating agencies (CRAs). Six years later, we want to verify if CRAs are still suffering a reputational damage by measuring stock prices reactions to rating announcements. To test our hypothesis we conduct an event analysis on the American, EU area and Asian/Pacific stock markets over a ten-year period from November 2003 to November 2013. We find that the postcrisis abnormal returns are in general lower if compared with the pre-crisis level, in particular if rating changes are far away from the speculative-junk border.
\end{abstract}

JEL Codes: JEL: G12, G14 and G24.

\section{Introduction}

At the time of the subprime crisis, investors strongly blamed credit rating agencies (CRAs) for failing in evaluating the credit risk of collateralized securities and, more in general, the probability of default of issuer companies, giving misleading, if not wrong, signals to the market. Therefore, in this paper we want to verify if CRAs are still suffering a reputational damage by measuring stock prices reactions to rating announcements. Our assumption is that, if the market is still considering rating agencies unable to produce additional and reliable information, it should not react to rating actions or react less than before the subprime crisis.

We adopt a global perspective and test our hypothesis with an event study on the biggest fifty stocks of the American, European and Asian markets, over a decade from November 2003 to November 2013. We then analyse 1455 rating events, quite a large sample compared to other studies on the same topic. Distinctive feature of this work is the aim of better understand whether the impact of the subprime crisis on credit ratings' credibility changes in different times, immediately after the Lehman bankruptcy as well as years later. In fact, the market could have a short memory and, after a while, forget the past, or remain impressed by extraordinary events and never forgive the responsible agents.

As known, rating agencies play a fundamental role in the financial market. They contribute to reduce information asymmetry by providing information on the creditworthiness of issuers and, at the same time, they are the cornerstone of banking and financial regulations. As a result, market participants are forced to use credit ratings, despite their effective information content and their accuracy. Therefore, to capture the market reactions to rating announcements actually driven by investors behaviours and not by

\footnotetext{
${ }^{1}$ Prof. Eleonora Isaia, Department of Management, University of Torino, Corso Unione Sovietica 218 bis, Torino, Italy. Email : eleonora.isaia@unito.it.

Prof. Marina Damilano, Department of Management, University of Torino, Corso Unione Sovietica 218 bis, Torino, Italy. Email marina.damilano@unito.it

Prof. Cristina Rovera, Department of Management, University of Torino, Corso Unione Sovietica 218 bis, Torino, Italy. Email: cristina.rovera@unito.it
} 


\section{Isaia, Damilano \& Rovera}

regulatory requirements, we observe the abnormal returns of those transactions far away from to the speculative-junk border, where trading is free and not substantially affected by prudential rules, and we compare these outcomes with the abnormal returns to rating changes close to the border and thus compulsory driven by regulatory constraints.

We find that the post-crisis market reactions are in general lower if compared with the precrisis level, in particular when ratings are far away from the threshold, i.e. where the market activity is not contaminated by prudential rules. With these findings we aim to contribute to the current debate on the role that rating agencies still have and should have at the light of one of the most severe financial crisis of the last century.

The paper is organised as follows. Beside section 1 that contains the introduction, section 2 presents the literature review, section 3 describes the methodology and the data sets, section 4 discusses our main findings and finally section 5 draws the conclusions.

\section{Literature Review}

The literature on rating is extensive. One branch of the scientific literature deals with the conflict of interest related to the rating agencies. Our paper, instead, pertains to another branch of the literature. It focuses on the market responsiveness to rating changes. The work of Gonzalez, Haas, Johannes, Persson, Toledo, Violates, Wieland and Zins (2004) offers a literature review of the effects of ratings on market dynamics. Further in-depth analysis on the topic can be found in the works of Katz (1974), Hand, Holthausen and Leftwich (1992), Followill and Martell (1997), Liu, Seyyed and Smith (1999), Steiner and Heinke (2001), Ammer and Clinton (2004), Linciano (2004), Martell (2005), Afonso, Furceri and Gomes (2012), Grothe (2013) who claim that downgrades have, on average, a greater impact than upgrades have. Although many papers test the market reactions to rating changes of bond, stock and CDS markets in different geographical areas and across the subprime crisis, quite a few try to gauge the reputational damage suffered by the rating agencies during and after the crisis. With respect to previous works on the same topic, the present analysis tries to move forward going more deeply inside the long crisis and, at the same time, considering the potential influence of the regulatory constraints on the market activities. In fact, the length of the crisis is subdivided in sub periods, to isolate the most severe phenomena immediately after the Lehman collapse, and the market reactions to rating agencies is observed close to or far away from the investment-speculative threshold, to capture the influence of the regulatory constraints.

The parameters on the basis of which a rating is determined are investigated in the works of Norden and Weber (2004), Micu, Remolona and Wooldridge (2006), Steiner and Heinke (works previously quoted), Opp C., Opp M., and Harris (2005), Jorion and Zhang (2006), Hill, Brooks and Faff (2010), Arezki, Candelon and Sy (2011), lannotta, Nocera and Resti (2013), Bar-Isaac and Shapiro (2013).

Norden and Weber have proved whether S\&P, Moody's and Fitch can or cannot convey new information to the market. Steiner and Heinke give instead great importance to the security issuers' country, while Arezki, Candelon and Sy dwell upon the type of announcement and upon the issuer agency. Jorion and Zhang maintain that the market response might also depend on the value of the rating preceding the announcement. With the help of empirical tests, the authors demonstrate greater price changes when low ratings are issued. lannotta, Nocera and Resti insist on the opacity of negotiation procedures, reducing in this way the explanatory power of ratings and the interpretation of 


\section{Isaia, Damilano \& Rovera}

results, while Bar-Isaac and Shapiro dwell on the economic cycle under way, by observing its countercyclical trend over the ratings quality: lower ratings accuracy in boom times and higher accuracy in recessionary times.

\section{The Methodology}

The sample consists of 1455 rating revisions from November 1 st 2003 to November 1 st 2013. The type of rating actions taken into consideration are restricted to S\&Ps, Fitch and Moody's issuer rating, long term issuer default and outlook, with positive and negative watches, if there. Rating actions and all the data have been extracted from the Bloomberg database. In order to standardize the conventional alpha-numerical scales used by the three CRAs, we covert their ratings into a single numerical scale that goes from excellent to poor: AAA (or similar) is equal to 1, while B- (or similar), which is the lowest rating of our sample, is equal to 16 . The positive and negative watches are equal to $-0,25$ and $+0,25$ respectively.

Our analysis considers the 150 most representative companies in the American, Euro zone and Asian/Pacific markets selected by using the components of the following bluechip regional indexes: STOXX USA 50, EURO STOXX 50 and STOXX Asia/Pacific 50.

The time frame has been split into three shorter sub-periods, in order to gauge the impact of the sub-prime mortgages financial crisis on the reliability of rating agencies:

a) pre-crisis (01/11/2003-15/09/2008, Lehman Brothers bankruptcy);

b) crisis (i.e. the peak of the crisis, 16/09/2008-15/10/2009, when the Vix index returns to the pre-crisis mean level);

c) post-crisis (16/10/2009-01/11/2013).

The main characteristics of the sample are summarized in Table 1. The table shows a prevalence of downgrades (584) compared to upgrades (462). Moreover, it can be noted how $32 \%$ of downgrades is contaminated, i.e. affected by an earlier rating revision occurred in the previous month, compared with $18 \%$ of the upgrades.

For what concerns the composition of the sample by the category of the issuer company, about $2 / 3$ of rating events involve non-financial firms (which represent $76 \%$ of the firms in our sample), with an almost consistent distribution between downgrades and upgrades, while financial companies (including banks) show an imbalance in favor of downgrades. As a consequence of the markets turmoil originated by the sub-prime crisis, most of the downgrades (65\%) were recorded in the years following the Lehman Brothers bankruptcy, while the same percentage refers to the upgrades in the pre-crisis period. 
Table 1 - Classification of rating events (November 1st 2003 - November 1st 2013)

Downgrade Upgrade Outlook $\begin{gathered}\text { Other } \\ \text { events (a) }\end{gathered}$

\begin{tabular}{|c|c|c|c|c|c|}
\hline & \multicolumn{5}{|c|}{ By rating agency } \\
\hline Fitch & 160 & 93 & 78 & 46 & 377 \\
\hline Moody's & 175 & 111 & 118 & 30 & 434 \\
\hline Standard \& Poor's & 249 & 258 & 106 & 31 & 644 \\
\hline \multicolumn{6}{|l|}{ of which: } \\
\hline \multirow{3}{*}{$\begin{array}{l}\text { - contaminated } \\
\text { - anticipated by watch }\end{array}$} & 187 & 83 & 162 & 25 & 457 \\
\hline & 111 & 54 & - & - & 165 \\
\hline & \multicolumn{5}{|c|}{ By category of the issuer company } \\
\hline \multirow{2}{*}{$\begin{array}{l}\text { Financial companies } \\
\text { of which: } \\
\text { - banks }\end{array}$} & 227 & 132 & 79 & 18 & 456 \\
\hline & 144 & 83 & 45 & 8 & 280 \\
\hline \multirow{3}{*}{$\begin{array}{l}\text { Non-financial firms } \\
\text { Total }\end{array}$} & 357 & 330 & 223 & 89 & 999 \\
\hline & 584 & 462 & 302 & 107 & 1455 \\
\hline & \multicolumn{5}{|c|}{ By period of time } \\
\hline Pre-crisis & 202 & 298 & 45 & 60 & 605 \\
\hline Crisis & 124 & 26 & 16 & 19 & 185 \\
\hline \multirow[t]{3}{*}{ Post-crisis } & 258 & 138 & 241 & 28 & 665 \\
\hline & 584 & 462 & 302 & 107 & 1455 \\
\hline & \multicolumn{5}{|c|}{ By geographical area } \\
\hline USA & 200 & 123 & 91 & 42 & 456 \\
\hline $\begin{array}{l}\text { Euro zone } \\
\text { of which: }\end{array}$ & 275 & 202 & 114 & 34 & 625 \\
\hline - Belgium & 0 & 3 & 3 & 2 & 8 \\
\hline - Germany & 69 & 50 & 36 & 7 & 162 \\
\hline - Spain & 63 & 37 & 9 & 1 & 110 \\
\hline - France & 72 & 68 & 44 & 20 & 204 \\
\hline - Ireland & 4 & 3 & 3 & 1 & 11 \\
\hline - Italy & 61 & 28 & 11 & 0 & 100 \\
\hline - The Netherlands & 6 & 13 & 8 & 3 & 30 \\
\hline $\begin{array}{l}\text { Asia } \\
\text { of which: }\end{array}$ & 109 & 137 & 97 & 31 & 374 \\
\hline - Australia & 43 & 32 & 28 & 12 & 115 \\
\hline - Hong Kong & 3 & 4 & 6 & 2 & 15 \\
\hline - Japan & 63 & 97 & 57 & 17 & 234 \\
\hline - Singapore & $\begin{array}{c}0 \\
584\end{array}$ & $\begin{array}{c}4 \\
462\end{array}$ & $\begin{array}{c}6 \\
302\end{array}$ & $\begin{array}{c}0 \\
107\end{array}$ & $\begin{array}{c}10 \\
1455\end{array}$ \\
\hline
\end{tabular}

Notes: (a) Other events include ratings confirmed, deleted or with developing watches.

Considering now the geographical areas, the sample has been divided into 477 observations related to companies listed in Euro zone markets, 323 related to American issuers and 246 related to Asian companies located in Australia, Japan, Hong Kong or Singapore. However, the cross-analysis of sub-samples portrayed in Table 2 shows a 


\section{Isaia, Damilano \& Rovera}

greater incidence of downgrades in the United States during the peak of the financial crisis (2008-2009) and referred to financial and banking companies only.

Table. 2 - Distribution of rating events by sub-samples

\begin{tabular}{|c|c|c|c|c|c|c|}
\hline & \multicolumn{6}{|c|}{ US } \\
\hline & \multicolumn{3}{|c|}{ Downgrades } & \multicolumn{3}{|c|}{ Upgrades } \\
\hline & $\begin{array}{l}\text { Financial } \\
\text { companies }\end{array}$ & $\begin{array}{c}\text {-of } \\
\text { which: } \\
\text { banks }\end{array}$ & $\begin{array}{c}\text { Non- } \\
\text { financial } \\
\text { firms }\end{array}$ & $\begin{array}{l}\text { Financial } \\
\text { companies }\end{array}$ & $\begin{array}{c}\text {-of } \\
\text { which: } \\
\text { banks }\end{array}$ & $\begin{array}{c}\text { Non- } \\
\text { financial } \\
\text { firms }\end{array}$ \\
\hline Pre-crisis & 26 & 11 & 56 & 27 & 17 & 55 \\
\hline Crisis & 45 & 27 & 15 & 4 & 2 & 3 \\
\hline \multirow[t]{4}{*}{ Post-crisis } & 29 & 18 & 29 & 4 & 1 & 30 \\
\hline & \multicolumn{6}{|c|}{ EU } \\
\hline & \multicolumn{3}{|c|}{ Downgrades } & \multicolumn{3}{|c|}{ Upgrades } \\
\hline & $\begin{array}{l}\text { Financial } \\
\text { companies }\end{array}$ & $\begin{array}{c}\text {-of } \\
\text { which: } \\
\text { banks }\end{array}$ & $\begin{array}{l}\text { Non- } \\
\text { financial } \\
\text { firms }\end{array}$ & $\begin{array}{c}\text { Financial } \\
\text { companies }\end{array}$ & $\begin{array}{c}\text {-of } \\
\text { which: } \\
\text { banks }\end{array}$ & $\begin{array}{l}\text { Non- } \\
\text { financial } \\
\text { firms }\end{array}$ \\
\hline Pre-crisis & 9 & 6 & 84 & 35 & 24 & 86 \\
\hline Crisis & 20 & 10 & 23 & 3 & 2 & 11 \\
\hline \multirow[t]{4}{*}{ Post-crisis } & 74 & 58 & 65 & 22 & 15 & 45 \\
\hline & \multicolumn{6}{|c|}{ ASIA } \\
\hline & \multicolumn{3}{|c|}{ Downgrades } & \multicolumn{3}{|c|}{ Upgrades } \\
\hline & $\begin{array}{l}\text { Financial } \\
\text { companies }\end{array}$ & $\begin{array}{c}\text {-of } \\
\text { which: } \\
\text { banks }\end{array}$ & $\begin{array}{l}\text { Non- } \\
\text { financial } \\
\text { firms }\end{array}$ & $\begin{array}{l}\text { Financial } \\
\text { companies }\end{array}$ & $\begin{array}{c}\text {-of } \\
\text { which: } \\
\text { banks }\end{array}$ & $\begin{array}{l}\text { Non- } \\
\text { financial } \\
\text { firms }\end{array}$ \\
\hline Pre-crisis & 1 & 1 & 26 & 26 & 17 & 69 \\
\hline Crisis & 5 & 2 & 16 & 1 & 1 & 4 \\
\hline Post-crisis & 18 & 11 & 43 & 10 & 4 & 27 \\
\hline
\end{tabular}

Table 3 shows the distribution of rating events by the category of investment grade versus speculative grade. Data show the obvious predominance within the sample of companies with a good credit quality (observations that fall within the investment grade category are 1090 and represent $97 \%$ of the total number of events, excluding outlooks). In the present analysis, the Euro zone stands out for the largest number of events registered in the rating grades known as "border" (between the BBB+/Baa1 rating classes and BB-/Ba3). 
Table 3 - Distribution of rating events by category: investment vs. speculative grade Investment Speculative Total

grade grade

$\begin{array}{cc}\text { of which: } & \text { of which: } \\ \text { current } & \text { current or } \\ \text { rating } & \text { last rating } \\ \text { border } & \text { border }\end{array}$

\section{By time span}

\begin{tabular}{lccccc} 
Pre-crisis & 525 & 22 & $\mathbf{5 4 7}$ & 127 & 156 \\
Crisis & 157 & 1 & $\mathbf{1 5 8}$ & 32 & 33 \\
Post-crisis & 408 & 5 & $\mathbf{4 1 3}$ & 98 & 116 \\
\multicolumn{1}{l}{ Total } & $\mathbf{1 0 9 0}$ & $\mathbf{2 8}$ & $\mathbf{1 1 1 8}$ & $\mathbf{2 5 7}$ & $\mathbf{3 0 5}$
\end{tabular}

By geographical area

\begin{tabular}{|c|c|c|c|c|c|}
\hline USA & 338 & 8 & 346 & 40 & 52 \\
\hline EU & 500 & 3 & 503 & 142 & 168 \\
\hline Asia & 252 & 17 & 269 & 75 & 85 \\
\hline Total & 1090 & 28 & 1118 & 257 & 305 \\
\hline
\end{tabular}

In conclusion, one comment on the distribution of rating events per year. Figure 1 represents the evolution of the total number of observations - highlighting the number of events with positive or negative watch in a separate bar -, distributed by downgrade, upgrade and outlook.

Fig. 1 - Distribution of rating events per year (November 2003 -November 2013)

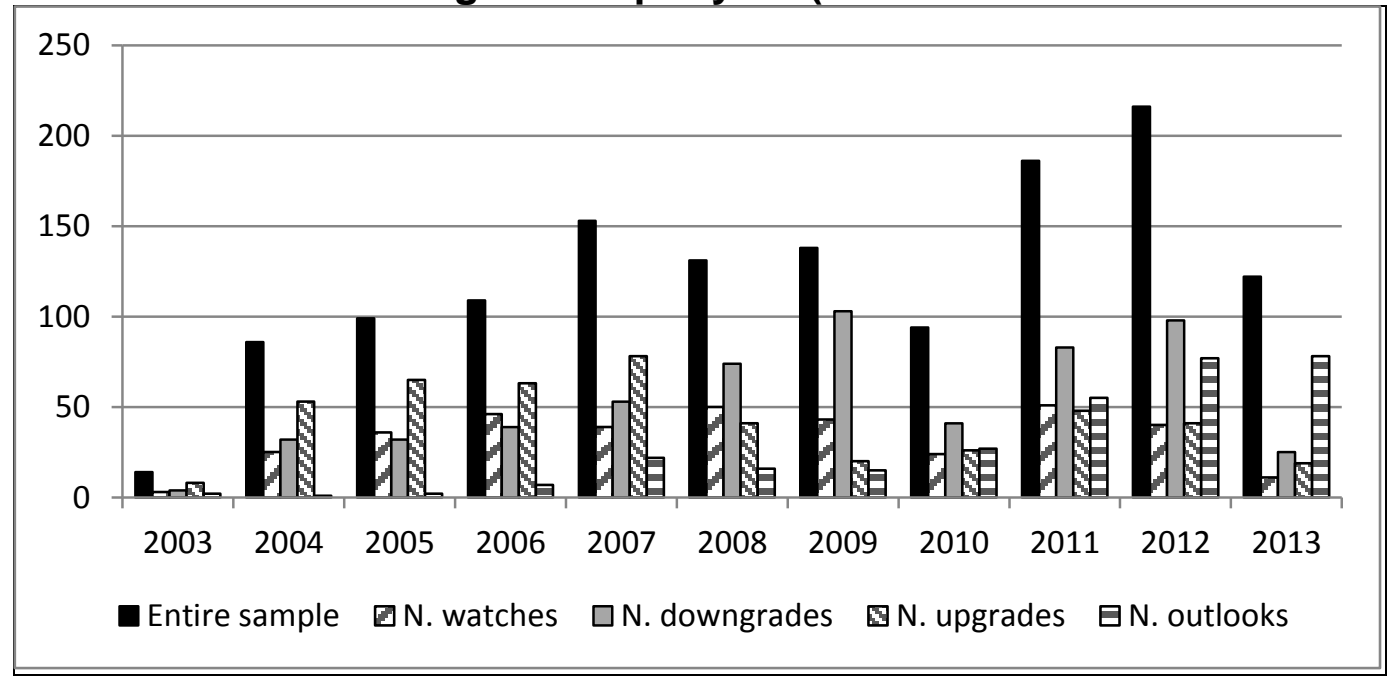

To test our hypothesis, i.e. to verify if CRAs have suffered and are still suffering a reputational damage by measuring stock prices reactions to rating announcements, we conduct an event analysis on our sample. Thus, for all stocks under revision, we calculate the cumulative abnormal return (CAR) over a $[-1 ;+1]$ day window around the rating event, following the CAPM and estimating Beta over a 500-day window. Then, we conduct a multivariate OLS regression: our dependent variable is the absolute value of the 3-day cumulative abnormal return, ABS_CAR, following Grothe (2013), as we want to analyze the size and not the sign of the market reaction. The independent variables are detailed in table 4. 


\section{Isaia, Damilano \& Rovera}

In line with previous works on the topic, they are mainly related to: the crisis/post-crisis period, the type of rating action, the market condition, the nature of the issuer company and the geographical area. The first key issue of our research is the time period. On the basis of our hypothesis, we expect market reactions to rating changes to be lower in the post-crisis then in the crisis and pre-crisis periods. In fact, if investors do not longer rely on rating announcements or, at least, rely less than in the past, they do not immediately trade the security under revision. Therefore, the expected sign of the DUMMY_POST CRISIS is negative, indicating a lower expected abnormal return or, in other words, a reduced market impact of rating actions after the subprime crisis. This phenomenon is expected to be stronger in the banking and financial sectors and reflected in a positive coefficient for the DUMMY_FINANCIAL.

The second key issue of this research is to sterilize the market activity from the influence of the certification role of rating agencies. To this end, we introduce two dummies, border and no-border, to separate the market-induced trading from the regulation-induced trading around the investment-speculative threshold, and we interact these two variables with the post-crisis variable. The expected sign of the BORDER-POSTCRISIS is uncertain, as the mandatory regulation displays a significant impact on the market activity, whether or not investors believe in rating announcements. On the contrary, the expected sign of the NOBORDER-POSTCRISIS is negative, signaling the loss of credibility and reliability suffered by rating agencies during the crisis. We then use two control independent variables, the VIX index and the STANDARD DEVIATION of each security, whose signs are expected to be positive: the higher the volatility of the stock and/or the market, the bigger the abnormal return.

Finally, we use geographical variables for the US, EU and ASIAN markets included in our sample to verify whether CRAs' reputational damage is delimited to the United States or spread with the same intensity all over the world. In regards to the European stock market, as the global financial crisis has turned into the sovereign debt crisis, we add a temporal dummy to capture the SOVEREIGN DEBT CRISIS impact for those countries of your sample (Ireland, Italy, Spain and France) affected by this additional domestic instability. 
Table 4 - Independent variables of the OLS regression

\begin{tabular}{|c|c|c|}
\hline Name & Definition & $\begin{array}{l}\text { Expected } \\
\text { sign of the } \\
\text { coefficient }\end{array}$ \\
\hline DUMMY_CRISIS & $\begin{array}{l}\text { Dummy variable which is equal to } 1 \text { for all rating } \\
\text { actions between September } 15,2008 \text { and October } \\
15,2009 \text { and } 0 \text { otherwise. }\end{array}$ & $?$ \\
\hline DUMMY_POSTCRISIS & $\begin{array}{l}\text { Dummy variable which is equal to } 1 \text { for all rating } \\
\text { actions after October } 15,2009 \text { and } 0 \text { otherwise. }\end{array}$ & - \\
\hline VIX & $\begin{array}{l}\text { Value of the VIX index on the announcement day of } \\
\text { the rating action. }\end{array}$ & + \\
\hline DEVST & $\begin{array}{l}\text { Standard deviation of the 50-day daily returns } \\
\text { preceding the rating action for the specific stock } \\
\text { under revision. }\end{array}$ & + \\
\hline DUMMY_FINANCIAL & $\begin{array}{l}\text { Dummy variable which is equal to } 1 \text { if the rating } \\
\text { action concerns a financial company and } 0 \\
\text { otherwise. }\end{array}$ & + \\
\hline BORDER_POSTCRISIS & $\begin{array}{l}\text { Dummy variable that is equal to } 1 \text { if the rating } \\
\text { action is in the post-crisis period and concerns a } \\
\text { company whose last or current ratings are between } \\
\text { BBB+ and BB- (speculative-junk grade border) and } \\
0 \text { otherwise. }\end{array}$ & $?$ \\
\hline NOBORDER_POSTCRISIS & $\begin{array}{l}\text { Dummy variable that is equal to } 1 \text { if the rating } \\
\text { action is in the post-crisis period and concerns a } \\
\text { company whose last or current ratings are not } \\
\text { between BBB+ and BB- (speculative-junk grade } \\
\text { border) and } 0 \text { otherwise. }\end{array}$ & - \\
\hline WATCH_POSTCRISIS & $\begin{array}{l}\text { Dummy variable that is equal to } 1 \text { if the rating } \\
\text { action is in the post-crisis period and consists in a } \\
\text { credit warning instead of a downgrading or } \\
\text { upgrading and } 0 \text { otherwise. }\end{array}$ & - \\
\hline DUMMY_US & $\begin{array}{l}\text { Dummy variable which is equal to } 1 \text { if the rating } \\
\text { action concerns an American company and } 0 \\
\text { otherwise. }\end{array}$ & - \\
\hline DUMMY_EU & $\begin{array}{l}\text { Dummy variable which is equal to } 1 \text { if the rating } \\
\text { action concerns a Euro area company and } 0 \\
\text { otherwise. }\end{array}$ & - \\
\hline $\begin{array}{l}\text { DUMMY_EU2_CTRY } \\
\text { SOVCRISIS }\end{array}$ & $\begin{array}{l}\text { Dummy variable which is equal to } 1 \text { if the rating } \\
\text { action concerns a Euro area company involved in } \\
\text { the sovereign crisis (Ireland, Italy Spain, and } \\
\text { France) and } 0 \text { otherwise. The Euro area sovereign } \\
\text { crisis period has been defined from April } 1,2010 \text { to } \\
\text { December } 31,2012 \text {. }\end{array}$ & + \\
\hline
\end{tabular}

\section{The Findings}

Findings are summarized in table 5. If we first focus on the entire sample, column (1) shows that ABS_CARs are bigger when the market and the stock itself are more volatile, as well as during the peak of the crisis period. Nevertheless, it has to be noticed that in our sample we have some abnormal observations (defined based on 3 standard deviations of the standardized residuals), equivalent to 1 per cent of the sample, quite a reasonable number if we consider that we analyze the biggest financial crisis of the last century. To fit our model to these data, we use a dummy variable for each of them, even if we do not include their coefficients and $\mathrm{P}$-values in table 5. All of them have a positive sign and a 
statistical significance at 1 per cent level. Therefore, outlier observations display a strong explicative power.

In column (2) we add some independent variables in order to improve the estimation model and better evaluate the market reaction to rating announcements during the postcrisis period. To this end, we use three interaction variables, NOBORDER_POSTCRISIS, BORDER_POSTCRISIS and WATCH_POSTCRISIS, and we include the DUMMY_FINANCIAL. In line with our research question, the absolute value of abnormal cumulative returns are lower if compared with the pre-crisis level for those ratings far away from the speculative-junk border, where the market activity is not contaminated by regulatory constraints. On the contrary, the market reaction around the threshold is not significant and does not exhibit any difference with respect to the pre-crisis period. Credit warnings seem to maintain their informative power, as generally proved in literature, even if this evidence is not confirmed in the further sub-sample analysis and almost always is not significant. The DUMMY_FINANCIAL has a positive coefficient and is statistically significant indicating that financial firms have been experienced higher abnormal returns than non-financial companies both in the crisis and post-crisis periods. This result confirms our expectations, since banks and financial firms have been swamped by the long wave of Lehman collapse.

Column 3 restricts the sample only to banks and confirms that rating agencies lose their informative power and/or their credibility when they do not display their certification role. In fact, the negative sign and the significant P-value of the NOBORDER_POSTCRISIS show that the market reaction far from the borderline is lower than in the pre-crisis period. The same result, i.e. the lower market reaction compared to the pre-crisis span, is obtained around the critical threshold, but in this case it is not statistically significant. Furthermore, DUMMY_US indicates that the negative impact of the subprime crisis on the rating agencies reliability is stronger in the US stock market.

Then, we test the same model of column 2 on the financial and non-financial sub-samples. Results are omitted, but they confirm lower CARs in absolute value in the no-border market activity in the post-crisis years, even if the evidence is weaker for non-financial firms suggesting that rating agencies might have suffered a stronger reputational damage in the banking and financial sector.

Finally, columns (4) to (6) compare the three different geographical areas. Each regression confirms our main finding, that is NOBORDER_POSTCRISIS with negative sign and statistical significance. In the EU sub-sample - column 6 - the effect of the subprime crisis on rating agencies credibility is mixed with the impact of the sovereign crisis, that scattered on the so called Euro2 countries. Nevertheless, the DUMMY_EU2_CTRY_SOVCRISIS does not display a significant explicative power suggesting that deeper investigation is needed. We will take it into consideration in the further steps of our research project. 
Table 5 - Explicative variables of the ABS_CAR

\begin{tabular}{|c|c|c|c|c|c|c|}
\hline & (1) & (2) & (3) & (4) & (5) & (6) \\
\hline & $\begin{array}{l}\text { Entire } \\
\text { sample }\end{array}$ & $\begin{array}{l}\text { Entire } \\
\text { sample }\end{array}$ & $\begin{array}{c}\text { Sub- } \\
\text { sample } \\
\text { BANKS }\end{array}$ & $\begin{array}{c}\text { Sub- } \\
\text { sample } \\
\text { US }\end{array}$ & $\begin{array}{c}\text { Sub- } \\
\text { sample } \\
\text { EU }\end{array}$ & $\begin{array}{c}\text { Sub- } \\
\text { sample } \\
\text { ASIA }\end{array}$ \\
\hline C & $\begin{array}{c}0.006 \\
(1.987)\end{array}$ & $\begin{array}{c}0.003 \\
(0.882)\end{array}$ & $\begin{array}{l}-0.002 \\
(-0.698)\end{array}$ & $\begin{array}{c}0.000 \\
(0.042)\end{array}$ & $\begin{array}{c}0.004 \\
(1.053)\end{array}$ & $\begin{array}{l}-0.011 \\
(2.221)\end{array}$ \\
\hline DUMMY_CRISIS & $\begin{array}{l}0.014^{* * *} \\
(2.978)\end{array}$ & $\begin{array}{l}0.012^{* *} \\
(2.042)\end{array}$ & $\begin{array}{c}0.017 \\
(1.270)\end{array}$ & $\begin{array}{c}0.014 \\
(1.185)\end{array}$ & $\begin{array}{c}0.006 \\
(0.821)\end{array}$ & $\begin{array}{c}0.005 \\
(0.538)\end{array}$ \\
\hline $\begin{array}{l}\text { DUMMY_POST } \\
\text { CRISIS }\end{array}$ & $\begin{array}{l}-0.003^{* *} \\
(-2.305)\end{array}$ & & & & & \\
\hline VIX & $\begin{array}{c}0.0007^{* * *} \\
(3.760)\end{array}$ & $\begin{array}{l}0.000^{\star * *} \\
(3.737)\end{array}$ & $\begin{array}{l}0.001^{* *} \\
(2.214)\end{array}$ & $\begin{array}{l}0.001^{* *} \\
(2.300)\end{array}$ & $\begin{array}{l}0.000^{*} \\
(1.654)\end{array}$ & $\begin{array}{l}0.002^{*} \\
(1.656)\end{array}$ \\
\hline DEVST & $\begin{array}{l}0.294^{\star * *} \\
(2.361)\end{array}$ & $\begin{array}{c}0.210 \\
(1.501)\end{array}$ & $\begin{array}{l}0.629^{* *} \\
(2.382)\end{array}$ & & $\begin{array}{c}0.719^{* \star *} \\
(3.001)\end{array}$ & $\begin{array}{c}0.444 \\
(1.656)\end{array}$ \\
\hline $\begin{array}{l}\text { NOBORDER_POST } \\
\text { CRISIS }\end{array}$ & & $\begin{array}{l}-0.007^{\star \star * *} \\
(-3.291)\end{array}$ & $\begin{array}{l}-0.012^{\star \star} \\
(-2.091)\end{array}$ & $\begin{array}{l}-0.009^{\star \star} \\
(-2.391)\end{array}$ & $\begin{array}{l}-0.007^{\star \star} \\
(-1.856)\end{array}$ & $\begin{array}{c}-0.010^{\star * *} \\
(-2.919)\end{array}$ \\
\hline $\begin{array}{l}\text { BORDER_POST } \\
\text { CRISIS }\end{array}$ & & $\begin{array}{c}0.002 \\
(0.817)\end{array}$ & $\begin{array}{l}0.001 \\
(0.936)\end{array}$ & $\begin{array}{l}-0.011^{*} \\
(-1.777)\end{array}$ & $\begin{array}{c}0.001 \\
(0.323)\end{array}$ & $\begin{array}{c}0.001 \\
(0.183)\end{array}$ \\
\hline $\begin{array}{l}\text { WATCH_POST } \\
\text { CRISIS }\end{array}$ & & $\begin{array}{c}0.005 \\
(1.638)\end{array}$ & $\begin{array}{l}0.001 \\
(0.804)\end{array}$ & $\begin{array}{c}-0.002 \\
(-0.874)\end{array}$ & $\begin{array}{c}0.000 \\
(0.087)\end{array}$ & $\begin{array}{c}0.019^{* \star *} \\
(2.659)\end{array}$ \\
\hline DUMMY_FINANCIAL & & $\begin{array}{l}0.006^{* * *} \\
(2.898)\end{array}$ & & $\begin{array}{l}0.005^{*} \\
(1.663)\end{array}$ & $\begin{array}{c}0.002 \\
(1.023)\end{array}$ & $\begin{array}{l}-0.005^{\star *} \\
(-2.140)\end{array}$ \\
\hline DUMMY_US & & & $\begin{array}{l}-0.010^{* *} \\
(-1.995)\end{array}$ & & & \\
\hline $\begin{array}{l}\text { DUMMY_EU2_CTRY_ } \\
\text { SOV_CRISIS }\end{array}$ & & & & & $\begin{array}{c}0.002 \\
(0.714)\end{array}$ & \\
\hline Adjusted R2 & 0.79 & 0.79 & 0.46 & 0.87 & 0.35 & 0.65 \\
\hline N. observation & 1452 & 1117 & 213 & 346 & 503 & 268 \\
\hline
\end{tabular}

The t-stat are reported in brackets under each coefficient. White heteroskedasticity-consistent standard errors and covariance. ${ }^{*}=$ significant at $10 \%$ level; ${ }^{* *}=$ significant at $5 \%$ level; ${ }^{* * *}=$ significant at $1 \%$ level with a two-tailed test.

\section{Summary and Conclusions}

The paper presents an event analysis on 1455 observations to test whether credit rating agencies' reliability has been undermined by the subprime crisis. Our key assumption is that if the market reacts to any unpredictable and reliable information - such as a credit rating should be -, the stock under revision should register an abnormal return in the event window around the rating change announcement. In the same way, if ratings are no longer considered trustworthy and do not produce valuable information, the market should not react or react less than before. As rating agencies have been widely perceived to be one of the main contributors to the global financial crisis, we then expect a loss of their credibility in the post crisis period.

In line with previous works on the same topic, we consider the big distinction between the informative power and the regulatory function of CRAs and we select a decade across the subprime crisis. Nevertheless, in addition to the current body of literature that generally 


\section{Isaia, Damilano \& Rovera}

divides the period of time in before and after the crisis, just considering a precise reference point such as the date of the beginning of the crisis or the Lehman bankruptcy, in this paper we test the reputational damage in different periods of time. To reinforce our assumption, we isolate years 2008-2009, which represent the peak of the crisis, from 2010-2013 and test whether the reputational damage has been progressively dried up since the Lehman collapse. The findings of the analysis seem to prove the effectiveness of our research question: credit rating agencies have suffered a reputational damage after the subprime crisis. In fact, abnormal returns in the post-crisis period are significantly lower than in the pre-crisis, at least for those transactions far away from the investmentspeculative border, where trading is not strongly driven by regulatory constraints.

Our main funding is consistent even when we look at the sector subsamples and geographic subsample. In fact we can affirm that, in the banking and financial sectors as well as in the United States where the crisis was born, the phenomenon is stronger and shows that the faith on rating agencies' capacity to gauge credit risk has been undermined by the subprime crisis scandals. The market seems to have quite a good memory and does not longer blindly believe in rating announcements like before the crisis. Nevertheless the banking regulation entrusts the credit risk valuation to rating agencies, allowing CRAs to maintain their power and to condition the market. The so-called paradox of credit ratings is one more time confirmed.

New rules on credit rating agencies have been implemented after the subprime crisis to reinforce the regulatory framework, improve the quality of rating process, and reduce the overreliance on credit ratings and the power of CRAs. All these measures should have persuaded the market to restore confidence in credit ratings as truthful and neutral piece of information. A complete analysis of these rules and regulations is well beyond the purpose of this paper. Nevertheless, it would be interesting to analyze whether the impact of new regulations has produced a positive effect on CRAs reputation and cleaned up the reputational damage arisen from the subprime crisis. Unfortunately, the range of the regulatory measures is too recent to be evaluated on our sample.

We could overcome this limit of our analysis extending the observation period, as well as we could improve the robustness of our findings, investigating separately abnormal returns in downgrades and upgrades subsamples. At this stage of the analysis, we analyze the size and not the sign of market reactions to rating changes, since we are interested in the market movement itself and not in its direction. Previous works often show that the market reacts more strongly to rating downgrades and credit watch than to rating upgrades. Thus, a further step to be done is an in depth-analysis to assess the degree of this credit market information asymmetry.

\section{Endnotes}

*This paper belongs to a larger research project on rating actions undertaken by the University of Torino, Italy. Findings are presented in two working papers: Isaia-Damilano-Rovera (2014) and De Vincentiis-Pia, Aftermath of the subprime crisis: reputational damages suffered by major and minor rating agencies, (2014), that focuses only on the banking sector and compare the reputational damage suffered by major and minor rating agencies.

\section{References}

Acharya, VV and Johnson, TC 2007, 'Insider trading in credit derivatives', Journal of Financial Economics, no. 84, pp. 110-141. 


\section{Isaia, Damilano \& Rovera}

Afonso, A, Furceri, D, Gomes, P 2012, 'Sovereign credit ratings and financial markets linkages: Application to European data', Journal of International Money and Finance, no. 31, pp. 606-638.

Ammer, J and Clinton, N 2004, 'Good News Is No News? The Impact of Credit Rating Changes on the Pricing of Asset-Backed Securities', Board of Governors of the Federal Reserve System - International Finance Discussion Papers, no. 809.

Arezki, R, Candelon, B, Sy, ANR 2011, 'Sovereign Rating News and Financial Markets Spillovers: Evidence from the European Debt Crisis', IMF Working Paper, no. 68.

Ferreira, MA and Gama, PM 2007. 'Does sovereign debt ratings news spill over to international stock markets?', Journal of Banking \& Finance, no. 31, pp. 3162-3182.

Followill, RA and Martell, T 1997, 'Bond Review and Rating Change Announcements: An Examination of Informational Value and Market Efficiency', Journal of Economics and Finance, vol. 2, no. 2, pp. 75-82.

Gonzalez, F, Haas, F, Ronald, J, Persson, M., Toledo, L., Violi, R., Wieland, M., Zins, C. 2004, 'Market dynamics associated with credit ratings. A literature review', $E C B$ Occasional Paper series, no. 16.

Grothe, M 2013, 'Market pricing of credit rating signals', ECB Working Paper series, no. 1623.

Hand, JRM, Holthausen, RW, Leftwich, RW 1992, 'The Effect of Bond Rating Agency Announcements on Bond and Stock Prices', The Journal of Finance, vol. 47, no. 2, pp. 733-752.

Han, SH, Pagano, MS, Shin, YS 2012, 'Rating Agency Reputation, the Global Financial Crisis, and the Cost of Debt', Financial Management, vol. 41, no. 4, pp. 849-884.

Iannotta, G, Nocera, G, Resti, A 2013, 'Do Investors care about Credit Ratings? An Analysis through the Cycle', Journal of Financial Stability, vol. 9, no. 4, pp. 545-555.

Liu, P, Seyyed, FJ, Smith, SD 1999, 'The Independent Impact of Credit Rating Changes. The Case of Moody's Rating Refinement on Yield Premiums', Journal of Business Finance \& Accounting, vol. 26, no. 3-4, pp. 337-363.

Micu, M, Remolona, E, Wooldridge, P. 2006, 'The price impact of rating announcements: which announcements matter?', BIS Working paper, no. 207.

Mollemans, M 2003, 'The Credit Ratings Announcement Effect in Japan', Working paper series SSRN.

Norden, L and Weber, M 2004, 'Informational efficiency of credit default swap and stock markets: The impact of credit rating announcements', Journal of Banking \& Finance, no. 28, pp. 2813-2843.

Opp, C, Opp, M, Harris, M 2013, 'Rating Agencies in the Face of Regulation', Journal of Financial Economics, vol. 108, no. 1, pp. 46-61.

Steiner, M and Heinke, VG 2001, 'Event Study concerning international bond price effects of credit rating actions', International Journal of Finance and Economics, no. 6, pp. 139-157. 